\title{
IMPACT OF SURROUNDINGS LANDSCAPE STRUCTURE ON FORMATION OF PLANT SPECIES IN AFFORESTRATED MANOR PARKS
}

\author{
FORNAL-PIENIAK, B. ${ }^{1}-$ OLLIK, $\mathrm{M}^{2}{ }^{2}-$ SCHWERK, A. ${ }^{3 *}$ \\ ${ }^{I}$ Faculty of Horticulture, Biotechnology and Landscape Architecture, Department of \\ Environmental Protection, Warsaw University of Life Sciences - SGGW \\ Nowoursynowska Street 166, 02-787 Warsaw, Poland \\ (phone: +48-22-59-32066; fax: +48-22-853-0944) \\ ${ }^{2}$ Faculty of Agriculture and Biology, Department of Experimental Design and Bioinformatics, \\ Warsaw University of Life Sciences - SGGW \\ Nowoursynowska Street 166, 02-787 Warsaw, Poland \\ (phone: +48-22-59-32727; fax: +48-22-59-32722) \\ ${ }^{3}$ Faculty of Horticulture, Biotechnology and Landscape Architecture, Laboratory of Evaluation \\ and Assessment of Natural Resources, Warsaw University of Life Sciences - SGGW \\ Nowoursynowska Street 166, 02-787 Warsaw, Poland \\ (phone: +48-22-59-32224; fax: +48-22-59-32227) \\ *Corresponding author \\ e-mail: aschwerk@yahoo.de \\ (Received 13 $3^{\text {th }}$ Jun 2018; accepted $2^{\text {nd }}$ Aug 2018)
}

\begin{abstract}
Manor parks established on oak-hornbeam habitat (Tilio-Carpinetum) are very characteristic elements of agricultural landscapes in Poland. In light of the loss of old growth oak-hornbeam forests because of deforestations, these habitats have the potential to become refuges. Thus, the aim of the study was to determine the influence of surroundings landscape structure on the development of the plant species composition on the herb layer in selected manor parks in the southern part of Poland. The study was conducted in 60 manor parks located in southern Poland characterized by differences in land use of the surroundings. Manor parks located close to forest were characterized by higher numbers of forest plant species in the herb layer. Both the percentage share of the Tilio-Carpinetum species and the percentage share of ancient forest species were increased in parks adjacent to forests. However, forest size seems to be of minor importance. Indicator plant species for manor parks adjacent to villages as well as indicator species for parks nearby forests could be identified. The results of the study are important for landscape planners and landscape ecologists in order to formulate directions of shaping and management of rural landscapes including manor parks.
\end{abstract}

Keywords: Forest species, Ancient species, Tilio-Carpinetum, Landscape ecology, Poland

\section{Introduction}

The impact of anthropogenic and natural factors is important for shaping the species composition of the forest herbaceous layer (Verheyen et al., 2003; Hale et al., 2006; Verheyen et al., 2012; Hofmeister et al., 2013). The diversity of the forest herb layer constitutes the largest fraction of the total plant diversity in deciduous forests (Gilliam, 2007; Alberdi et al., 2010). The distribution of forest species in human-dominated forests and agroforests varies as a function of the species traits that are vulnerable to disturbance and fragmentation (Carreneo-Rocabado et al., 2012). Characteristics of a habitat patch and its surrounding matrix and the degree of fragmentation are important determinants of plant species composition (Honnay et al., 2005; Moxham and Turner, 
2011; Aggemyr and Cousins, 2012; Amici et al., 2015, Ojoyi et al., 2015; Pao and Upadhaya, 2017). Therefore, the floristic diversity and forest plant species composition of isolated patches is limited (Ewers and Didham, 2006; Tscharntke et al., 2012), based on the relative importance of the landscape and habitat factors.

Herbaceous plants are very dynamic so they are suitable indicators of changes of habitats in short time (Alberdi et al., 2010; Del Vecchio et al., 2016). Among them, a special role can be attached to ancient forest plant species. Ancient forest plant species are plants that are characteristic of ancient woodlands (older than 200 years) and old woodlands (200-100 years old) according to Wulf (2003). The list of ancient forests indicator species for Central and Western Europe was proposed by Hermy et al. (1999). Then, for Polish conditions it was complemented by Dzwonko and Loster (2001). In this context the role of the forest islands in the agricultural landscape was determined as the places of forest flora refuges (Wojcik, 1991; Dzwonko and Loster, 1992; Dzwonko and Gawroński, 1994; Braun and Koch, 2016). Ancient plants are proper indicators of long term continuity of the habitat (Hermy et al., 1999; Nordén and Appelqvist, 2001; Verheyen et al., 2003; Kolb and Diekmann, 2004; Stefanska-Krzaczek et al., 2016; Lalechère et al., 2017; Webb and Goodenough, 2018). The degree of naturalness of forests is one of the attributes for the assessment of the ecological stability of forests (Macků, 2012).

Many of the vascular species that grow in these forests have slow dispersal mechanisms and/or rely heavily upon the forest structure for survival (Webb and Goodenough, 2018). Secondary forests located close to an ancient forest are often distinguished by a high abundance of "ancient forest species" (Brunet and von Oheimb, 1998; Hermy and Verheyen, 2007), despite colonization by "ancient forest species" (Hermy et al., 1999) demands a lot of time (e.g. Dupouey et al., 2002). Mixed-oakhornbeam forests are one of the potentially dominant forest vegetations in Eastern Europe (Matuszkiewicz et al., 2013). Mixed forests provide with habitat for a rich biodiversity and their decline in abundance has endangered a large number of species (Berg et al., 1994). The herbaceous understory plays a key role during restoration of the biodiversity of forest plantations (Gilliam, 2007). Agricultural landscape fragmentation in central Europe has resulted in decreased species richness in the forest herbaceous layer (Honnay et al., 1999; Mortelliti et al., 2010). Deforestation and forest management have resulted in a negligible share of the oak-hornbeam forests in the total forest area in Poland (Matuszkiewicz et al., 2013). Manor parks are an essential part of the Polish countryside. Most of the manor parks were established on oak-hornbeam habitat (TilioCarpinetum), and they were abandoned and uncultivated after World War II (FornalPieniak and Wysocki, 2009b). In light of the loss of old growth oak-hornbeam forests because of deforestations, manor park habitats have the potential to become refuges (Glendell and Vaughan, 2002; Jonsell, 2012; Liira et al., 2012). Forest plants of oakhornbeam forest (Tilio-Carpinetum) are very important for keeping the biodiversity of rural landscapes.

Therefore, it is important to analyze the impact of the surroundings forest landscape structure on the flora of the manor parks. However, studies dealing with the effects of the surroundings landscape structure on the development of the composition of plant species in herbaceous layer in manor parks in Poland are rare (Lirra et al., 2008; FornalPieniak and Wysocki, 2009a).

The aim of the study was to determine the influence of surroundings landscape structure on the development of the species composition of the herbaceous layer in four 
types of manor parks differing with respect to their surrounding in the Sandomierska Basin Region in Poland. It was tested, (1) whether the neighborhood of a forest influences the species composition and frequency of forest species in the herbaceous layer of manor parks, and (2) if there are existing characteristic / diagnostic species for different types of manor parks depending on the surroundings landscape structures. Since many forest species are sensitive to habitat fragmentation (Brunet et al., 2011), a special focus was set on forest plants from Tilio-Carpinetum as well as ancient forest plants.

\section{Materials and Methods}

\section{Study area and field methods}

The study was carried out in the area of the Sandomierz Basin (Fig. 1). 166 manor parks of the landscape style registered as historical monuments are located in this area. According to geobotanical division (Lencerewicz and Kondracki, 1959) the Sandomierz Basin belongs to the South Uplands area with a surface of about 14.5 thousand $\mathrm{km}^{2}$. It is situated between the Carpathian foothills, Miechów Upland, Sandomierz Upland and Roztocze and is a foreground of Carpathians (Starkel, 1999). Potential vegetation is represented by a mosaic of diverse habitats in the area of the Sandomierz Basin. The largest area of the Sadomierska Basin is occupied by forests represented by: Quercoroboris Pinetum, Serratulo-Pinetum, Tilio-Carpinetum, Lecobryo-Pinetum, CladonioPinetum and Molinio-Pinetum. Along watercourses especially the Vistula, San and Wisłoka habitats are lowland riverine riparian elm-ash forests (Ficario-Ulmetum minoris).

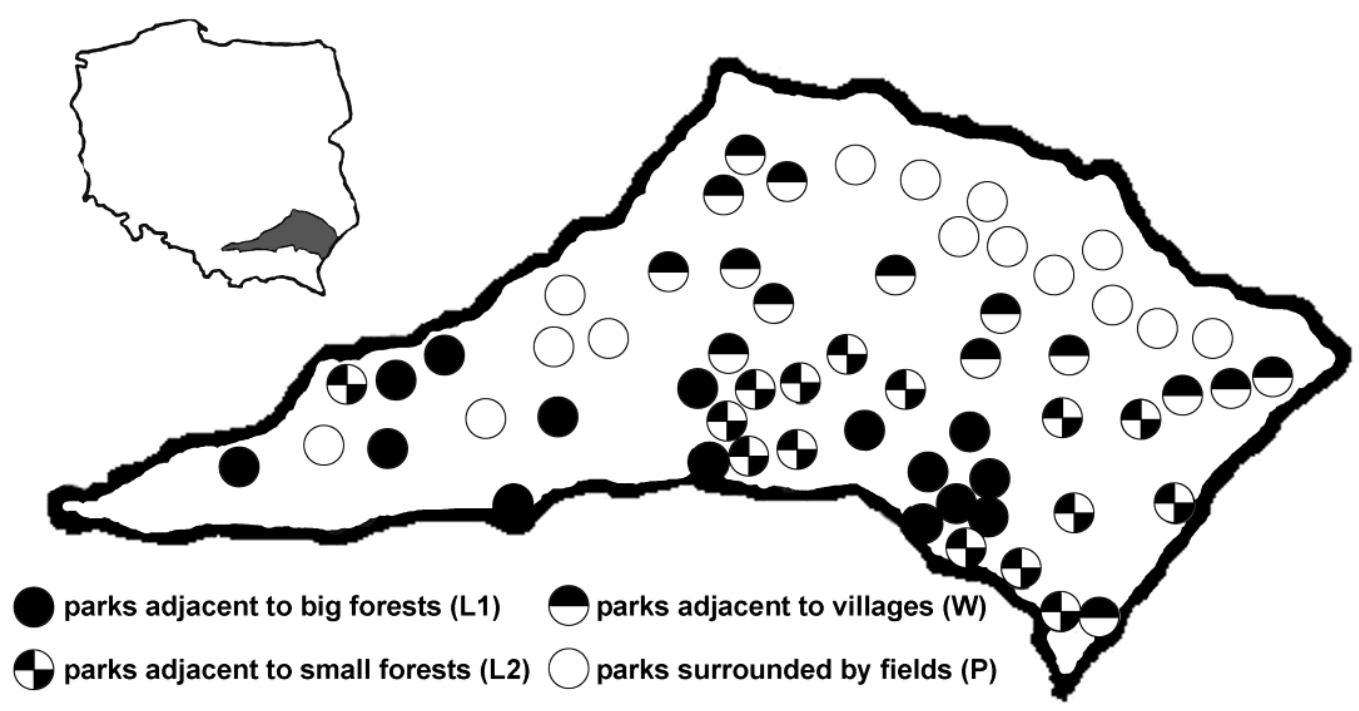

Figure 1. Location of the Sandomierz Basin area in Poland and location of the manor parks in the area

The manor parks were subjected to the following evaluation criteria: the same type of habitat, size of afforestrated areas, and landscape structures in the surrounding (size of the forests, fields, villages). Based on these criteria, 60 manor parks located in the 
Sandomierz Basin with 3 to 5 ha of afforestrated areas were selected for the study (Fig. 1). All these manor parks were established on oak-hornbeam habitat. Based on their specific localization the study objects were divided into four types of manor parks: 15 parks adjacent to big forests (L1), 15 parks adjacent to small forests (L2), 15 parks surrounded by fields (P), and 15 parks adjacent to villages $(\mathrm{W})$. The surrounding forests were growing on the same oak-hornbeam habitats as the manor parks. As big forests (L1) those with a size of 15 to 20 ha were defined and small forests (L2) had a size range from 2 to 4 ha. The studied parks surrounded by fields were located in a distance of at least $2 \mathrm{~km}$ from the nearest villages.

In the herbaceous layer of each manor park 10 phytosociological records using the Braun-Blanquet method (1951) were carried out during the spring and summer time in the years 2016-2017. Syntaxonomic division was made according to Matuszkiewicz (2008) and plant species were named according to Mirek et. al. (1995). Existing plant species were grouped according to naturalness of vegetation (Keddy, 2016). The degree of naturalness is often assessed by the similarity of a biocoenosis to the presumed natural state before it was affected by man (Reif and Walentowski, 2008). We distinguished according to Matuszkiewicz (2008) between plants of natural (forest plants), seminatural (meadows, pasture plants), and synantropical (segetal and ruderal plants) vegetation as well as companion species.

\section{Statistical methods}

In order to determine the influence of the surroundings on the species composition in the manor parks, it was first compared the share of the distinguished species groups based on the criteria of naturalness of vegetation (Keddy, 2016) between the four types of parks. It was calculated the percentage of species of the relevant groups on the whole species number for each plot (phytosociological record). The resulting values were averaged for each park type.

Next, it was studied a more detailed impact on the forest species in order to determine the degree of long term continuity of the habitat. For that purpose the influence of the park's neighborhood on two parameters was analyzed: the percentage share of Tilio-Carpinetum class species and the percentage share of ancient forest species on the whole number of species in the individual phytosociological records. The average share of both parameters and the significance of their differences for parks and park types was studied by two identical analyses, using a Generalized Linear Model with two categorical factors in a nested design. The main factor was park surrounding type (four types) and the nested factor was park (60 parks, 15 for each type). Each single record was a repetition (10 per each park). Because share of species (dependent variable) is a typical ratio variable (varying between 0 and 1) the beta distribution was chosen as model distribution and as a link function identity was selected (Song and Tan, 2000). Based on the adopted model, it is possible to assess not only the differences in the average share of forest species depending on the character of the park's neighborhood, but also to determine the magnitude of this difference to the variability between individual parks (of the same type). The statistical analyses were carried out using STATISTICA v. 10.5.

In order to detect characteristic / diagnostic species whose presence or absence depends on the forms of land use in the surrounding of the parks, the Classification And Regression Trees (CART) method was used (Breiman et al., 1984). As dependent variable park type was chosen. This is a categorical (qualitative) variable, determining a 
classification algorithm of CART. As independent variable the abundances of each species denominated in Braun-Blanquet scale were used. Single phytosociological records were used as repetitions, without considering their origin from a specific park, but considering their origin from a given group of parks.

Since the abundances were encoded as categorical variables, it was possible to evaluate the quality of the analysis. Splits consistent with an abundance gradient, i.e. lower values for one side compared to the other one, should be interpreted as real effect, whereas those with mixed low and high values for both sides should be interpreted as errors. Additionally, it was analyzed the secondary splits (near optimal variables) in order to detect all diagnostic species. Finally, it was checked the allocation of the records to the end nodes of the CART tree in order to discover any regularities. It especially focused on records causing inhomogeneities in the end nodes.

The CART analysis were carried out using R 3.4.1 (R Development Core Team, 2013) with rpart and rpart.plot libraries.

\section{Results}

In the herb layer of parks adjacent to the forest (L1 and L2 types) the forest species (natural vegetation) distinctly dominated, constituting approximately $85 \%$ of all species supplemented with associated companion species (Fig. 2). Other species representing seminatural and synantropical vegetation occurred only occasionally. In parks neighboring with villages or surrounded only by crop fields, an increase share of species which are no indicators of long term continuity of the habitat was noticeable, i.e. species representing synantropical and seminatural vegetation, which represented $20 \%$ and $10 \%$ of the species composition in village-adjacent parks (W) and $21 \%$ and $9 \%$ of the species composition in field-adjacent parks $(\mathrm{P})$ respectively.

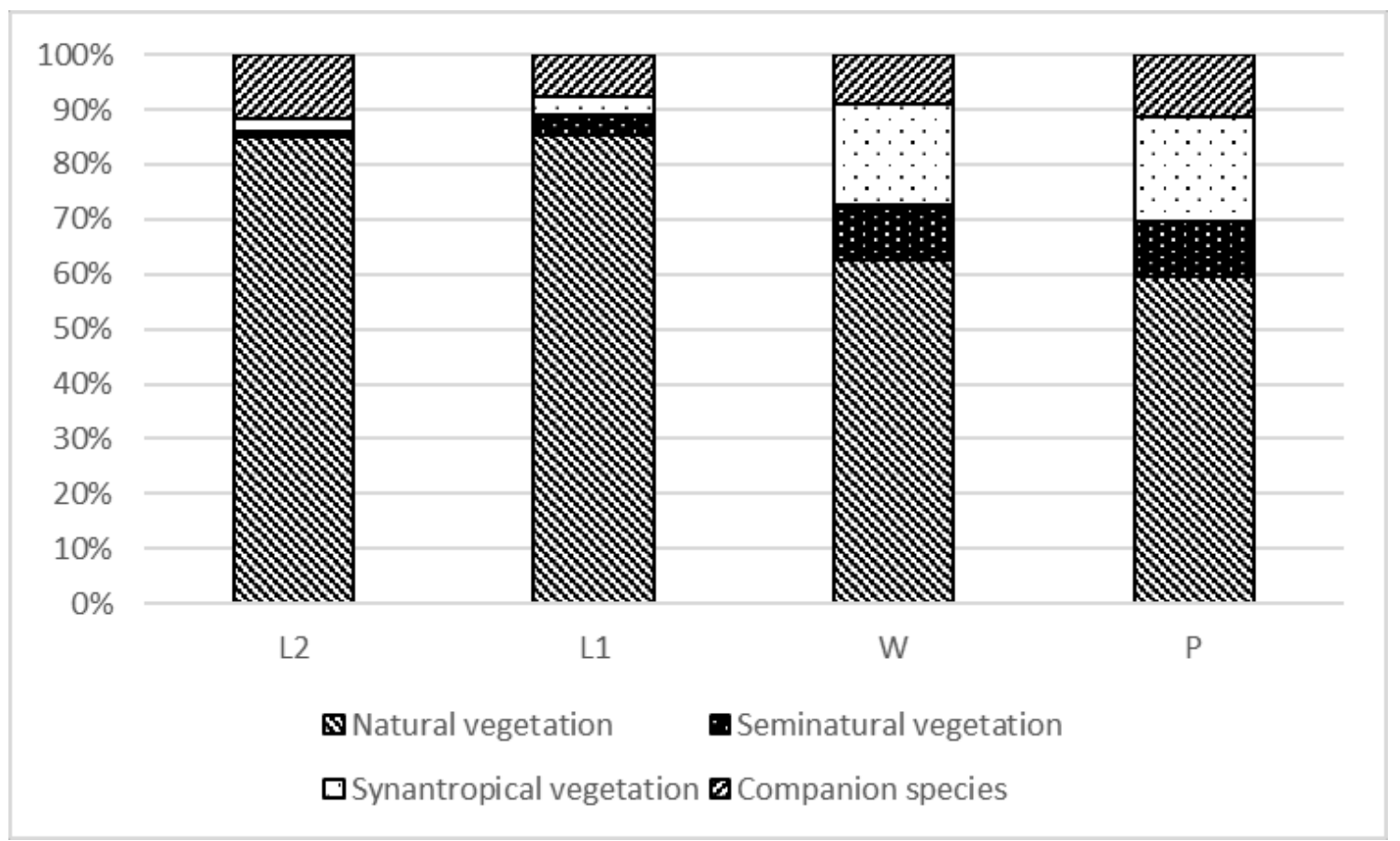

Figure 2. Mean percentage share of species belonging to different types of naturalness of vegetation for the four types of manor parks (L1, L2, W, P) 
The mean share of Tilio-Carpinetum species differed significantly $(\mathrm{p}<0.001)$ by type of park neighborhood (Fig. 3, Table 1). In forest-adjacent parks it reached $78 \%$ (L1) and $75 \%$ (L2) but in village-adjacent parks only $50 \%$ and in field-adjacent parks $47 \%$. The mean share of Tilio-Carpinetum species for single parks varied $(\mathrm{p}<0.001)$. However, for both types of forest-adjacent parks it fluctuated between $60 \%$ and $90 \%$ and for parks of type $\mathrm{W}$ and $\mathrm{P}$ between $40 \%$ and $60 \%$.

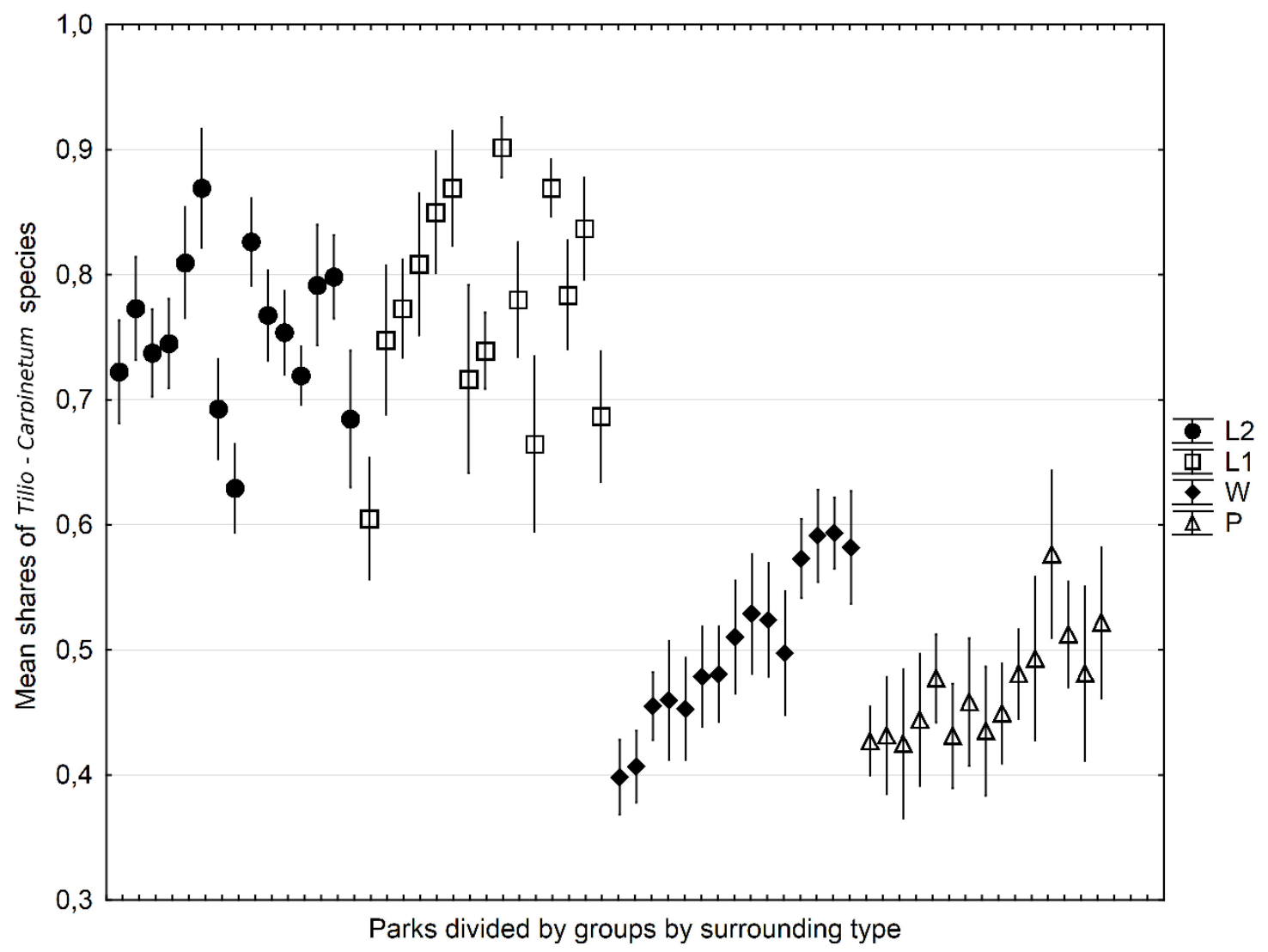

Figure 3. Mean percentage shares of Tilio-Carpinetum species per record in parks apportioned to type of surroundings ( $L 2, L 1, W, P)$. Bars show $95 \%$ confidence intervals

Table 1. GLM results of the effects of surrounding type and park on mean shares of TilioCarpinetum species per record

\begin{tabular}{lccccc}
\hline Factor & SS & df & MS & F & p \\
\hline Intercept & 234.9391 & 1 & 234.9391 & 58509.41 & 0.00 \\
Surrounding type & 11.8540 & 3 & 3.9513 & 984.05 & 0.00 \\
Park & 2.3582 & 56 & 0.0421 & 10.49 & 0.00 \\
Error & 2.1683 & 540 & 0.0040 & - & - \\
\hline
\end{tabular}

The share of ancient forest species showed a pattern similar to the shares of the TilioCarpinetum species (Fig. 4, Table 2). It was also significantly $(\mathrm{p}<0.001)$ higher for forest-adjacent parks (63\% for L1 and $70 \%$ for L2) than others (38\% for W and P). Similarly, we were able to observe a clear border between the average shares in 
individual parks. On all forest-adjacent parks it was above $42 \%$ and in the other below $42 \%$. The mean share of species for single parks varied too $(\mathrm{p}<0.001)$.

Two of the first splits of the CART analysis (Fig. 5) divided most of the records into more or less homogenous groups. An almost homogenous group containing 93 (out of 150) records from parks adjacent to villages (type $W$ ) with a small infusion of other types was extracted by the first node. The division criterion was the presence of Oxalis fontana (common yellow woodsorrel). The near optimal variables were the presence of Geranium sylvaticum (wood cranesbill), Convolvulus arvensis (field bindweed), and Chelidonium majus (greater celendine) and the absence of Melica nutans (mountain melick). The power of the alternative variables was not distinctly lower than that of the main variable. The second node was split on two descendants. The left (node 4) contained most of records from parks adjacent to forests (type L1 and L2), and the right (node 5) encompassed almost all records from parks surrounded only by agricultural land (type P). The left node (node 4) was distinguished by the presence of Melica nutans. The alternative criteria were the absence of Geranium sylvaticum, Allium ursinum (buckrams), Chelidonium majus and Lysimachia nummularia (moneywort). Practically, after the two first splits we obtained three groupings of nodes that correctly classified most of the records, but nodes 4 and 5 were not homogenous. The further splits represented purging efforts. Twenty-five type W parks were separated from node 4 based on the presence of Convolvulus arvensis, a higher abundance of Urtica dioica (common nettle) (more than 1 on the Braun-Blanquet scale) and a lower abundance of Lathyrus vernus (spring vetchling) as criteria.

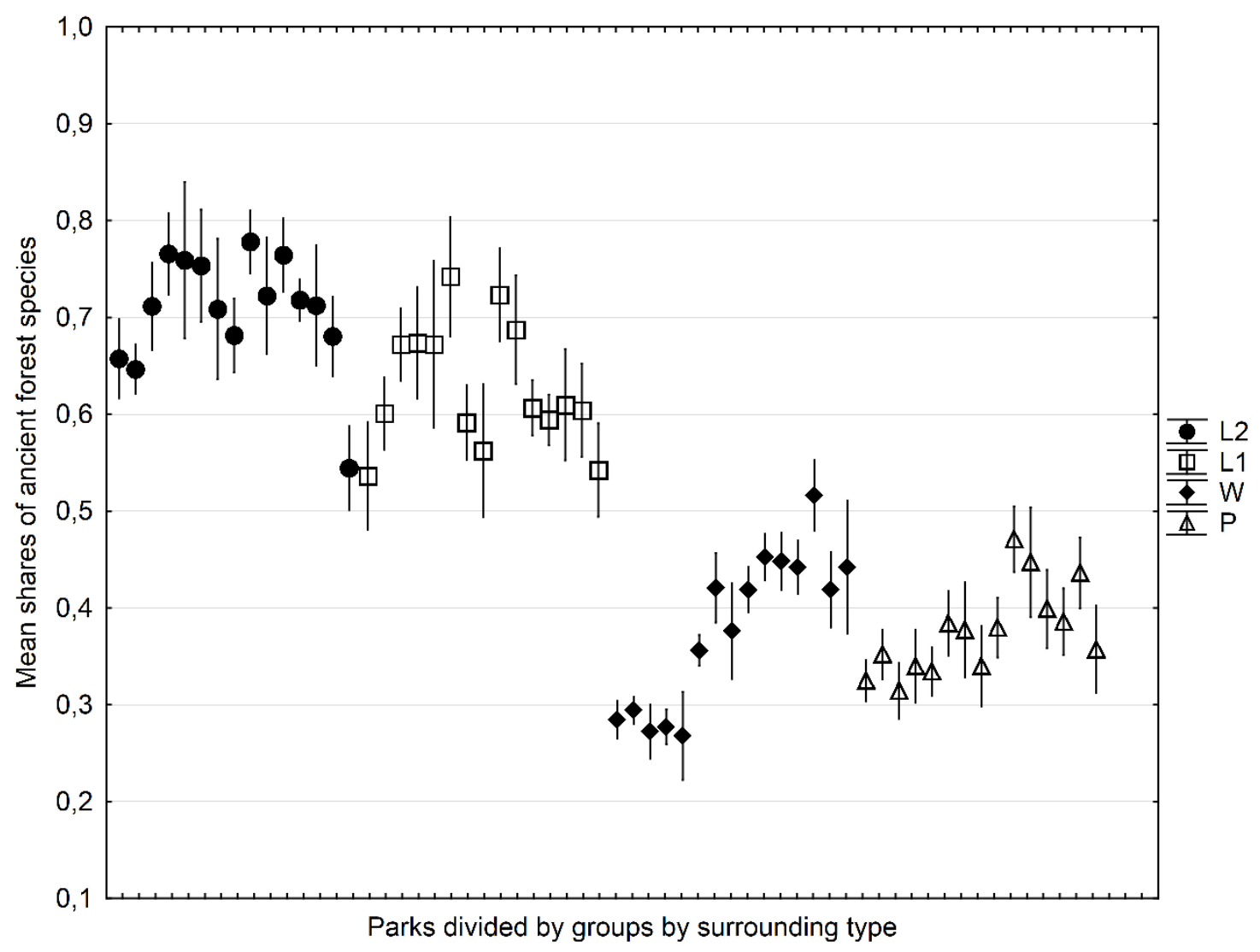

Figure 4. Mean shares of ancient forest species per record in parks apportioned to type of surroundings. Bars show $95 \%$ confidence intervals 
Table 2. GLM results of the effects of surrounding type and park on mean shares of TilioCarpinetum species per record

\begin{tabular}{lccccc}
\hline Factor & SS & df & MS & F & p \\
\hline Intercept & 163.8228 & 1 & 163.8228 & 43051.16 & 0.00 \\
Surrounding type & 13.0589 & 3 & 4.3530 & 1143.92 & 0.00 \\
Park & 2.2990 & 56 & 0.0411 & 10.7910 .79 & 0.00 \\
Error & 2.0549 & 540 & 0.0038 & - & - \\
\hline
\end{tabular}

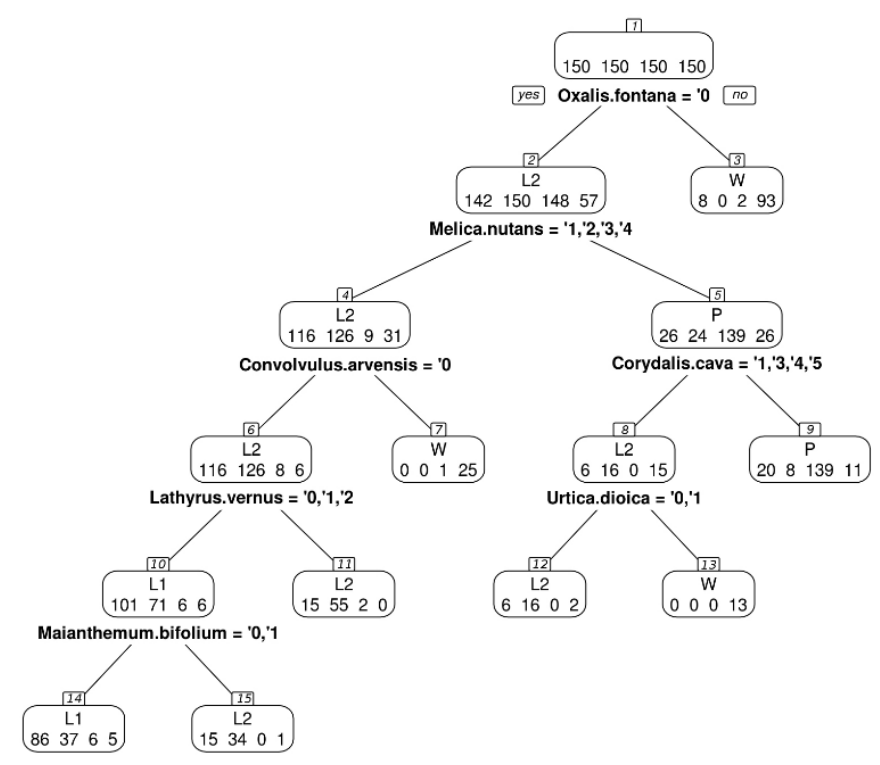

Figure 5. CART tree. The little squares above the nodes contain the node numbers. The type of extracted records and the quantities of records of each type, from left: L1, L2 P and W, are plotted in the node. Under the nodes are the names of the species that provide the criterion for division and the respective abundances denominated in Braun-Blanquet scale for the left descendant node

The CART analysis treated all records separately, but after the analysis, we checked the association between individual parks. We looked for patterns between records of type L1 and L2 from nodes 3 and 5 and between records of type P and W from node 4. Moreover, it was checked the association of records of type L1 and L2 with nodes 11, 14 and 15. In most cases, misclassification concerned single records from different parks, which could be considered as elements of statistical noise. Only two forest parks (L1, numbers 22 and 23) showed some distinctness. Most of the records were classified with $\mathrm{W}$ (in node 3 ) and $\mathrm{P}$ (in node 5) types.

\section{Discussion}

The study confirmed that the surroundings landscape structure influences the species composition and frequency of forest species in the herbaceous layer of manor parks (research question 1). Both the percentage share of Tilio-Carpinetum species and the percentage share of ancient forest species were increased in parks adjacent to forests. However, forest size seems to be of minor importance. Some species could be identified as characteristics for some of the studied park types (research question 2). 
The results are in agreement with other studies, which show that different management and human activities modify the species composition (Jamoneau et al., 2011), also in manor parks. Studies have shown that rural areas surrounding the parks, such as fields and built-up areas, have an impact on the appearance of non-forest plant species. Changes in habitat conditions have a strong impact on the occurrence of many ruderal plant species (Gawenda-Kempczyńska et al., 2017). An increased number of grasses and synantropical plants was observed in manor parks located nearby fields and village. According to Dzwonko and Gawroński (1994) and Bossuyt (2001) forest patches are very important for forests and ancient plants colonization. Forests patches have also positive effects with respect to natural regeneration of the herbaceous layer (Hill and Curran, 2003). Authors like LaPaix and Freedman (2010) and Liira et al. (2012) argue that forest stands, as well as the studied parks adjacent to the forests, can be suitable habitats for some forest species.

Large patches may be more important for maintaining the stability of populations (Ewers and Didham, 2006; Ǿkland et al., 2003; Honnay et al., 2005; Naaf and Kolk, 2015). According to Erikson (1996) many plants species characteristic for the herb layer of old forests have the ability to adapt to the new fragmented small and isolated forests in the agricultural landscape. However, the minimum size of forest islands in order to retain optimum conditions for forest species is an open question. Vestal and Heermans (1945) mention that the forest patches of an area of 1.6 ha and over retain forest plant species, but according to Levenson (1981) the critical value is 2.3 ha. Oostermeijer et al. (2003), stated that the reduction of the forest surface by fragmentation leads to reduction of the population of forest species. In addition, the size of the forest is obligatorily more important for plants that can grow only in forest communities (Kolb and Diekmann, 2004; Brunet et al. 2011). Higher species richness of plants was observed in bigger forest patches than in small ones (MacArthur and Wilson, 1967; Forman and Godron, 1986; Connor and McCoy, 1979, 2001; Saunders et al., 1991; Hill and Curran, 2001, 2003; Graae and Oakland, 2004). Some of the studied manor parks in the Sandomierz Basin area are adjacent to big forests, which might allow for a higher chance of the migration of forest plants into the parks. However, in this study we did not detect a clear influence of the size of the neighboring forests.

Size and management of the respective manor park is also of importance. A higher frequency and diversity of oak-hornbeam species in forests was observed in manor parks with a minimum area of 5 hectares (Fornal-Pieniak and Ollik, 2013). Studies by Fornal-Pieniak and Wysocki (2009a,b) on the vegetation of manor parks (2003-2007 and 2011-2012) allowed to confirm that mowing and the size of the forested timberland have an influence on the formation of the species composition of parks' undergrowth. In our study we observed a higher number of forest plants and ancient plants in manor parks, which were adjacent to forests. However, we analyzed only manor parks with afforestrated parts up to 5 ha. We can suppose that bigger afforestrated parts of manor parks could keep higher numbers of ancient and forest plant species. Yet, this is only an hypothesis which has to be verified by future research.

Another important factor affecting the number of forest species in the forest patches is their distance from forests with the same type of forest community (Dzwonko and Loster, 1988; Baker et al., 2013; Naaf and Kolk, 2015). Forest ecosystem fragmentation and habitat loss change spatial landscape features; consequently, fragmented and isolated habitats may vary more in terms of species composition than more connected habitats. The existence of forests adjacent to our studied manor parks facilitate the 
colonization of forests plants in these objects. In the agricultural landscape many forest species can survive only due to the presence of small residues of formerly large forest complexes, because they are quite vulnerable to anthropogenic pressure caused by humans (Wójcik, 1991; Anderson et al., 2007). Many of the vascular species that grow in these forests have slow dispersal mechanisms and/or rely heavily upon the forest structure for survival. Protection of these forest settings is essential for keeping biodiversity of rural environments (Webb and Goodenough, 2018).

Forest communities have a vertical structure which determines ecological conditions specific to each type of forest for plant species in the herbaceous layer. The CART analysis detected Oxalis fontana as the indicator plant species in parks adjacent to villages, where it was observed as a component of human activities or in their immediate surroundings. Alien species are indicators in a given area whose presence is due to human pressure, regardless of whether these activities are intentional or unintentional (Pysek et al., 2004). Oxalis fontana is an alien species which is classified as an agriophyte. Agriophytes are neophytes that penetrate natural habitats (Zając at el., 1998). According to Dajdak and Wuczyński (2008), Rzymowska and Skrajna (2015) and Kolářová et al. (2017) Oxalis fontana was found more frequently in cultivated fields (segetal habitats). In our study, Oxalis fontana occurred in manor parks adjacent to villages but also in two parks adjacent to forest (L1 numbers 22 and 23). However, these two parks were located near to small forests (approximately 3 ha) with high anthropogenic pressure. As source of the anthropogenic pressure the respective village located behind the forest, as seen from the park, may be assumed. Many footpaths were discovered, which were caused by local people crossing the forest when walking to the village. Therefore, Oxalis fontana was very common in two types of manor parks (W, P). According to Chmura (2004) and Kolářová et al. (2017) Oxalis fontana mostly occurs close to roads, footpaths and forest margins. Other indicators of anthropogenic pressure in our study were Geranium sylvaticum, Convolvulus arvensis, Chelidonium majus and Lysimachia nummularia.

Parks which are adjacent to forests were characterized by a higher share of forest and ancient plant species than the other manor parks. The CART method identified Melica nutans as indicator species for manor parks adjacent to forests (L1, L2). According to Zielewicz and Kozłowski (2011) the stand structure constitutes important ecological factors, especially the amount of light reaching to the bottom of the forest determines the changing participation of grass species. Grass species need large amounts of solar energy for initiation of their development. At the beginning of spring a higher proportion of coverage with grasses was observed, followed by a decrease with increasing density of tree canopies. Such conditions allow the occurrence of Melica nutans in the forests (Slezák et al., 2011). In our study we did not analyze the light factor and density of tree canopies in the manor parks, but it can be assumed that proper ecological conditions allowed the growing of Melica nutans in their herbaceous layer. Another species associated with forest in our study was Lathyrus vernus. Distinguishing the species composition of parks adjacent to larger (L1) and smaller (L2) forest was impossible. The splits after node 6 (group of most of L1 and L2 records) reflected the character of the park habitat (humidity or fertility) rather than the type of surroundings. Thus, it can be assumed that some species (e.g. Melica nutans) require natural forests in the surroundings and do not survive in isolated manor parks.

The results indicated that manor parks are important as "forest islands" in the agriculture landscape, because they contain ancient and forest plant species typical for 
Tilio-Carpinetum habitats. Because of their values, manor parks should be considered as important refuges in the ecological structure of the Sandomierz Basin. To formulate directions of shaping and management of rural landscapes including manor parks is a challenging task for landscape planners and landscape ecologists. In this context it is also recommended to monitor the impact of land-use practices, which are of particular importance with regard to biodiversity hotspots (Braun and Koch, 2016; Alphan, 2017) as Tilio-Carpinetum forests and manor parks.

\section{Conclusions}

Manor parks constitute a suitable habitat for survival of many forest species characteristic for oak-hornbeam forests and therefore are important ecological islands in the rural landscape. The surrounding of the parks decides to a large extent about the herb layer composition. Isolated parks are settled by a distinct lower number of forest species and numerous synantropical species. Some species (Melica nutans) cannot survive in isolated parks and occur only in those close to natural forest. However, forest size seems to be of minor importance. The results of the study are important for landscape planners and landscape ecologists in order to formulate directions of shaping and management of rural landscapes including manor parks.

Acknowledgements. The authors are grateful to Professor Czesław Wysocki for his valuable methodical remarks. This paper is communication no. 497 of the Laboratory of Evaluation and Assessment of Natural Resources, Warsaw University of Life Sciences - SGGW.

\section{REFERENCES}

[1] Aggemyr, E., Cousins, S. A. O. (2012): Landscape structure and land use history influence changes in island plant composition after 100 years. - Journal of Biogeography 39: $1645-1656$.

[2] Alberdi, I. S., Condés, S., Martínez-Millán, J. (2010): Review of monitoring and assessing ground vegetation biodiversity in national forest inventories. - Environmental Monitoring and Assessment 164: 649-676.

[3] Alphan, H. (2017): Analysis of landscape changes as an indicator for environmental monitoring. - Environmental Monitoring and Assessment 189: 24.

[4] Amici, V., Rocchini, D., Filibeck, G., Bacaro, G., Santi, E., Geri, F., Landi, S., Scoppola, A., Chiarucci, A. (2015): Landscape structure effects on forest plant diversity of local scale: Exploring the role of spatial extent. - Ecological Complexity 21: 44-52.

[5] Anderson, J., Rowcliffe, J., M., Cowlishaw, G. (2007): Does the matrix matter? A forest primate in a complex agricultural landscape. - Biological Conservation 135: 212-222.

[6] Baker, S. C., Spies, T. A., Wardlaw, T. J., Balmer, J., Franlin, J. F., Jordan, G. J. (2013): The harvested side of edges: Effect of retained forests on the re-establishment of biodiversity in adjacent harvested areas. - Forest Ecology and Management 302: 107121.

[7] Berg, A., Ehnstrom, B., Gustafsson, L., Hallingback, T., Jonsell, M., Weslien, J. (1994): Threatened plant, animal, and fungus species in Swedish forests: distribution and habitat associations. - Conservation Biology 8: 718-731.

[8] Bossuyt, B. (2001): Plant species and soil dynamics across ancient-recent forest ecotones: consequences for ecological restoration. - Ph.D. thesis, Catholic University of Leuven, Leuven. 
[9] Braun-Blanquet, J. (1951): Pflanzensoziologie, 2 Aufl. - Springer Verlag, Wien.

[10] Braun, A. Ch., Koch, B. (2016): Estimating impacts of plantation forestry on plant biodiversity in southern Chile - a spatially explicit modelling approach. - Environmental Monitoring and Assessment 188: 564.

[11] Breiman, L., Friedman, J. H., Olshen, R. A., Stone, C. J., (1984): Classification and Regression Trees. - Chapman \& Hall, Boca Raton.

[12] Brunet, J., von Oheimb, G. (1998): Migration of vascular plants to secondary woodlands in southern Sweden. - Journal of Ecology 86: 429-438.

[13] Brunet, J., Valtinat, K., Mayr, M. L., Felton, A., Lindbladh, M., Bruun, H. H. (2011): Understory succession in post-agricultural oak forests: Habitat fragmentation affects forest specialists and generalists differently. - Forest Ecology and Management 262: $1863-1871$.

[14] Chmura, D. (2004): Penetration and naturalisation of invasive alien plant species (neophytes) in woodlands of the Silesian Uplands (Southern Poland). - Nature Conservation 60: 3-11.

[15] Carreno-Rocabado, G., Pena-Claros, M., Bongers, F., Alarcon, A., Licona, J., Poorter L. (2012): Effects of disturbance intensity on species and functional diversity in a tropical forest. - Journal of Ecology 100: 1453-1463.

[16] Connor, E. F., McCoy, E. D. (1979): The statistics of the species area relationship. - The American Naturalist 113: 791-833.

[17] Connor, E. F., McCoy, E. D. (2001): Species-area relationships. - In: Levin, S. A. (ed.) Encyclopedia of Biodiversity 5, Academic Press, New York.

[18] Dajdak, Z., Wuczyński, A. (2008): Alien plants in field margins and fields of southwestern Poland. - Biodiversity Research and Conservation 9-10, 19-33.

[19] Del Vecchio, S., Slaviero, A., Fantinato, E., Buffa G. (2016): The use of plant community attributes to detect habitat quality in coastal environments. - AoB Plants 8: 1-14.

[20] Dupouey, J. L., Dambrine, E., Laffite, J. D., Moares, C. (2002): Irreversible impact of past land use on forest soils and biodiversity. - Ecology 83: 2978-2984.

[21] Dzwonko, Z., Loster, S. (2001): Wskaźnikowe gatunki roślin starych lasów i ich znaczenie dla ochrony przyrody i kartografii roślinności. Typologia zbiorowisk i kartografia roślinności w Polsce. - Prace Geograficzne 178: 119-132.

[22] Dzwonko, Z., Loster, S. (1988): The number and distribution of vascular plant species in islands forest communities in the norther part the west Carpathian Foothills. - Folia Geobotanica et Phytotaxonomica 23: 1-16.

[23] Dzwonko, Z., Gawroński, S. (1994): The role woodlands fragments, soil types, and dominant species in secondary succession on the western Carpatian foothills. - Vegetatio 111: 149-160.

[24] Dzwonko, Z., Loster, S. (1992): Species richness and seed dispersal to secondary woods in southern Poland. - Journal of Biogeography 19: 195-204.

[25] Eriksson, O. (1996): Regional dynamics of plants: a review of evidence of remnant, source-sink, and metapopulations. - Oikos 77: 248-258.

[26] Ewers, R. M., Didham, R. K. (2006): Confounding factors in the detection of species responses to habitat fragmentation. - Biological Reviews 81: 117-142.

[27] Forman, R. T. T., Godron, M. (1986): Landscape Ecology. J. - Wiley and Sons, New York.

[28] Fornal-Pieniak, B., Ollik, M. (2013): Diversity of flora in the undergrowth of park afforestations, rural plantings and oak-hornbeam forests. - Folia Forestalia Polonica A 55: $132-136$.

[29] Fornal-Pieniak, B., Wysocki, Cz. (2009a): Typy parków wiejskich w krajobrazie rolniczym na przykładzie Krainy Kotlina Sandomierska. - Woda-Środowisko-Obszary Wiejskie 9: 51-57. 
[30] Fornal-Pieniak, B., Wysocki, Cz. (2009b): Diversity of ancient forest plant species in country parks. - Annals of Warsaw University of Life Sciences - SGGW, Horticulture and Landscape Architecture 30: 201-205.

[31] Gawenda-Kempczyńska, D., Iwona Paszek, I., Załuski, T. (2017): Regeneration of vegetation in manor park in Laskowice (Dąbrowa Forest District). - Ecological Questions 27: 39-52.

[32] Gilliam, F. S. (2007): The ecological significance of the herbaceous layer in temperate forest ecosystems. - Bioscience 57: 845-858.

[33] Glendell, M.,Vaughan, N. (2002): Foraging activity of bats in historic landscape parks in relation to habitat composition and park management. - Animal Conservation 5: 309_ 316.

[34] Graae, B. J., Oakland, R. H. (2004): Influence of historical, geographical and environmental variables on understory composition and richness in Danish forest. Journal of Vegetation Science 15: 465-474.

[35] Hale, C. M., Frelich, L. E., Reich, P. B. (2006): Changes in hardwood forest understorey communities in response to European earthworm invasions. - Ecology 87: 1637-1649.

[36] Hermy, M., Verheyen, K. (2007): Legacies of the past in the present-day forest biodiversity: a review of past land-use effects on forest plant species composition and diversity. - Ecological Research 22: 361-371.

[37] Hermy, M., Honnay, O., Firbank, L., Grashof-Bokdam, C., Lawesson, J. E. (1999): An ecological comparison between ancient and other forest plant species of Europe and the implications for forest conservation. - Biological Conservation 91: 9-22.

[38] Hill, J. L., Curran, P. J. (2001): Species composition in fragmented forest: conservation implications of changing forest area. - Applied Geography 21: 157-174.

[39] Hill, J. L., Curran, P. J. (2003): Area, shape, and isolation of tropical forest fragments: effects on tree species diversity and implications for conservations. - Journal of Biogeography 30: 1391-1403.

[40] Hofmeister, J., Hosek, J., Brabec, M., Hédl, R., Modry, M. (2013): Strong influence of long-distance edge effect on herb-layer vegetation In forest fragments in an agricultural landscape. - Perspectives in Plant Ecology, Evolution and Systematics 15: 293- 303.

[41] Honnay, O., Hermy, M., Coppin, P. (1999): Effects of area, age and diversity of forest patches in Belgium on plant species richness, and implications for conservation and reforestation. - Biological Conservation 87: 73-84.

[42] Honnay, O., Jacquemyn, H., Bossuyt, B., Hermy, M. (2005): Forest fragmentation effects on patch occupancy and population viability of herbaceous plant species. - New Phytosociologist 166: 723-736.

[43] Jamoneau, A., Sonnier, G., Chabrerie, O., Closset-Kopp, D., Saguez, R., Gallet-Moron, E., Decocq, G. (2011): Drivers of plant species assemblages in forest patches among contrasted dynamic agricultural landscapes. - Journal of Ecology 99: 1152-1161.

[44] Jonsell, M. (2012): Old park trees as habitat for saproxylic beetle species. - Biodiversity and Conservation 2: 619-642.

[45] Keddy, P. A. (2016): Plant ecology. Origins. Processes. Consequences. - Cambrige University Press, Cambridge.

[46] Kolářová M., Tyšer, L., Krähmer, H. (2017): Occurrence of neophytes in agrophytocoenoses - field survey in the Czech Rebublic. - Acta Universitatis Agriculturae et Silviculturae Mendelianae Brunensis 65: 661-668.

[47] Kolb, A., Diekmann, M. (2004): Effects of environment, habitat configuration, and forest continuity on the distribution of forest plant species. - Journal of Vegetation Science 15: 199-208.

[48] Lalechère, E., Jabot, F., Archaux, F., Deffuant, G. (2017): Non-equilibrium Plant metapopulation dynamics challenge the concept of ancient/recent forest species. Ecological Modelling 366: 48-57. 
[49] LaPaix, R., Freedman, B. (2010): Vegetation structure and composition within urban parks of Halifax Regional Municipality Nova Scotia Canada. - Landscape and Urban Planning 98: 124-135.

[50] Lencewicz, S., Kondracki, J. (1959): Geografia fizyczna Polski. - Wydawnictwo PWN, Warszawa.

[51] Levenson, J. B. (1981): Woodlots as biogeographic islands in south landscapes. - In: Burgess R. L., Sharpe D. M. (ed.) Forest island dynamics in man-dominated landscapes, Springer-Verlag, New York, Heidelberg, Berlin.

[52] Liira, J., Lõhmus, K., Tuisk, E. (2012): Old manor parks as potential habitats for forest flora in agricultural landscape of Estonia. - Biological Conservation 146: 144-154.

[53] Lirra, J., Schmidt, T., Aavik, T., Arens, P., Augenstein, J., Bailey, D., Billeter, R., Bukáček, R., Burel, F., De Blust, G., De Cock, R., Dirksen, J., Edwards, P. J., Hamerský, R., Herzog, F., Klotz, S., Kühn, I., Le Coeur, D., Miklová, P., Roubalova, M., Schweiger, O., Smulders, M. J. M., van Wingerden, W. K. R. E., Bugter, R., Zobel, M. (2008): Plant functional group composition and large scale species richness in European agricultural landscape. - Journal of Vegetation Science 19: 3-14.

[54] Macků, J. (2012): Methodology for establishing the degree of naturalness of forest stands. - Acta Universitatis Agriculturae et Silviculturae Menselianae Brunensis 5: 161-165.

[55] MacArthur, R. H., Wilson, E. D. (1967). The theory of islands biogeography. - Princeton Univ. Press, Princeton.

[56] Matuszkiewicz, W. (2008): Przewodnik do oznaczania zbiorowisko roślinnych Polski. Wydawnictwo Naukowe PWN, Warszawa.

[57] Matuszkiewicz, J., M., Kowalska, A., Solon, J., Degórski, M., Kozłowska, A., RooZielińska, E., Zawiska, I., Wolski, J. (2013): Long-term evolution models of postagricultural forests. - IGiPZ PAN, Warsaw.

[58] Mirek, Z., Zając, M., Zając, A., Piękoś-Mirkowa, H. (1995): Vascular plants of Poland. A checklist. - W. Szafer Institue of Botany, Polish Academy of Sciences, Cracow.

[59] Mortelliti, A., Amori G., L. Boitani L. (2010): The role of habitat quality in fragmented landscapes: a conceptual overview and prospectus for future research. - Oecologia 163: 535-547.

[60] Moxham, C., Turner, V. (2011): The effect of fragmentation on the threatened plant community Coastal Moonah Woodland in Victoria, Australia. - Urban Ecosystems 14: 569-593.

[61] Naff, T., Kolk, J. (2015): Colonization credit of post-agricultural forest patches in NE Germany. - Biological Conservation 182: 155-163.

[62] Nordén, B., Appelqvist, T. (2001): Conceptual problems of ecological continuity and its bioindicators. - Biodiversity Conservation 10: 779-791.

[63] Ojoyi, M. Mutanga, O., Odindi, J. Aynekulu E., Abdel Rahman, E. (2015): The effect of forest fragmentation on tree species abundance and diversity in the eastern Arc Mountains of Tanzania. - Applied Ecology and Environmental Research 13: 307-324.

[64] Oostermeijer, J. G. B., Luijten, S. H., den Nijs, J. C. M. (2003): Integrating demographic and genetic approaches in plant conservation. - Biological Conservation 113: 389-398.

[65] Ǿkland, R. H., Rydgren, K., Ǿkland, T. (2003): Plant species composition of boreal spruce swamp forests: closed doors and windows of opportunity. - Ecology 84: 19091919.

[66] Pao, N.T., Upadhaya, K. (2017): Effect of fragmentation and anthropogenic disturbances on floristic composition and structure of subtropical broad leaved humid forest in Meghalaya, northeast India. - Applied Ecology and Environmental Research 15: 385407.

[67] Pysek, P., Richardson, D., M., Rejmanek, M., Webster, G., L., Williamson, M., Kirschner, J. (2004): Alien plants in checklists and floras: towards better communication between taxonomists and ecologists. - Taxon 53: 131-143. 
[68] R Development Core Team (2013): R: A Language and Environment for Statistical Computing. - R Foundation for Statistical Computing, Vienna.

[69] Reif, A., Walentowski, H. (2008): The assessment of naturalness and its role for nature conservation and forestry in Europe. - Waldökologie, Landschaftsforschung und Naturschutz 6: 63-76.

[70] Rzymowska, Z., Skrajna, T. (2015): Associations and communities of cereal crops of the Łuków Plain. Part III. Intermediate and impoverished communities. - Acta Agrobotanica 68: $17-22$.

[71] Saunders, D. A, Hobbs, R. J., Margules, C. R. (1991): Biological consequences of ecosystem fragmentation: A review. - Biological Conservation 5: 18-32.

[72] Slezák, M., Hegedušová, K., Senko, D. (2011): Syntaxonomy and ecology of forest vegetation in the Štiavnickě Vrchymts (Central Slovakia). - Acta Societatis Botanicorum Poloniae 80: 115-127.

[73] Song, P. X. K., Tan, M. (2000): Marginal models for longitudinal continuous proportional data. - Biometrics 56: 496-502.

[74] Starkel, L. (1999): Geografia Polski. Środowisko Przyrodnicze. - Wydawnictwo PWN, Warszawa.

[75] Stefańska-Krzaczek, E., Kacki, Z., Szypuła, B. (2016): Coexistence of ancient forest species as an indicator of high species richness. - Forest Ecology and Management 365: $12-21$.

[76] Tscharntke, T., Clough, Y., Wanger, T. C., Jackson, L., Motzke, I., Perfecto I., Vandermeer, J., Whitbread, A., (2012): Global food security, biodiversity conservation and the future of agricultural intensification. - Biological Conservation 151: 53-59.

[77] Verheyen, K., Baeten, L., De Frenne, P., Bernhardt-Römermann, M., Brunet, J., Cornelis, J., Decocq, G., Dierschke, H., Eriksson, O., Hédl, R., Heinken, T., Hermy, M., Hommel, P., Kirby, K., Naaf, T., Peterken, G., Petř́k, P., Pfadenhauer, J., Van Calster, H., Walther, G., R., Wulf, M., Verstraeten, G. (2012): Driving factors behind the eutrophication signal in understory plant communities of deciduous temperate forests. - Journal of Ecology 100: 352-365.

[78] Verheyen, K., Honnay, O., Motzkin, G., Hermy, M., Foster, D. R. (2003): Response of forest plant species to land-use change: a life-history trait-based approach. - Journal of Ecology 91: 563-577.

[79] Vestal, A. G., Heermans, M. F. (1945): Size requirements for reference areas in mixed forest. - Ecology 26: 122-134.

[80] Webb, J. C., Goodenough, A. E. (2018): Questioning the reliability of "ancient" woodland indicators: Resilience to interruptions and persistence following deforestation. - Ecological Indicators 84: 354-363

[81] Wójcik, Z. (1991). The vegetation of forest islands in the agricultural landscape of the Jorka river reception basin in Masurian Lakeland (north-east part of Poland). - Ekologia Polska 39: 437-479.

[82] Wulf, M. (2003): Preference of plant species for woodlands with differing habitat continuities. - Flora 198: 444-460.

[83] Zając, A., Zając, M., Tokarska-Guzik, B. (1998): Kenophytes in the flora of Poland: list, status and origin. - Phytocoenosis 10 (N.S.) Supplement of Cartography and Geobotany 9: 107-116.

[84] Zielewicz, W., Kozłowski, S. (2011): Występowanie barwników chlorofilowych i karotenowych w trawach leśnych. - Łąkarstwo w Polsce 14: 161-170. 